and more like chemists, but who are fellow members with him in the same college, and many of them at least his equal in general and professional knowledge. I could even point out a few of the fellows of the pure college of pure surgery who do what Mr. Bottomley charges general practitioners with doing-always excepting his felonious charge of selling spurious medicines, which I should be deeply sorry even to insinuate that any of my professional brethren ever did.

But my object is to reply to Mr. Bottomley's last letter, and his charges against the Council of the Institute, which are equally untrue and unfounded with his libels against general practitioners. In the first place, instead of referring to the recent documents of the Institute, which any candid man would have done, he quotes from a Report which is exactly two years old-and an admirable Report it is up to that time. It contains an account of the Conference meetings at the College of Physicians, including representatives from the Institute, at the request of Sir George Grey, with a view to an agreement of certain principles for legislation. It gives these "principles," as agreed to ; a copy of a charter of incorporation for an independent college of general practitioners; and the outline of a Bill founded on these principles and charter; with many other interesting documents, \&c.

Mr. Bottomley's first charge is, that the then proposed college of general practitioners would not be an independent one, because its members must also be enrolled in the College of Surgeons. And why was this? Just that Messrs. Bottomley and Co., and other cavillers, with all their successors, should still retain the title of surgeon, which at that time, as now, they were afraid of losing; but had Mr. Bottomley looked a little farther on, at the same page (47) from which he quotes, he would have also found that the College of Surgeons could not enrol a single member as a surgeon unless he had first been examined and approved by the College of General Practitioners. The two colleges were therefore to be co-ordinate and equally independent, as $\mathrm{Mr}$. Guthrie over and over asserted in his parliamentary evidence.

Mr. Bottomley's second charge is that of "duplicity" against the Institute for calling their college independent, - while he asserts it would be "under the control of the College of Surgeons as regards surgery ;" and yet he knows perfectly well that the conferences were broken up by the Institute, because the College of Surgeons would not concede the right to examine in surgery; and the Institute would not accept of a college without this power! and this they published to all the world! So much for Mr. Bottomley's ideas of "duplicity."

Mr. Bottomley's third charge is, that the registration fee for a general practitioner in only $£ 2$, while that for a physician or consulting surgeon is $£ 5$ : therefore the College of General Practitioners must of necessity be an inferior one! And he asserts that it is an iusult to common sense, and an absurdity, to suppose for a moment that the colleges could be co-equal and independent! Admirable logic. We again refer him to Mr Guthrie's evidence, (see pages 77 and 78 of the Institute's Report,) and we merely suggest, on the spur of the moment, that the registration fees were probably proportioned to the amount of fees obtained by the respective parties; but $\mathrm{Mr}$. Bottomley could easily surmount this immense difficulty by paying the higher fee of the pure surgeon, or the ten-guinea fee when he is created a fellow; an honour he has so long coveted!

The fourth charge is, "that the council of the Institute are promoting the efforts made by it (the College of Surgeons) to shake off all connexion with men who practise generally, thereby making it what its rulers are most desirous of doing, a Corukg of PURE SuRgery." This is indeed exactly what the college committes wish, and what, I think, they ought to be indulged in to their hearts' content; - let there be a College of Consulting Surgeons! Yet Mr. Bottomley, with characteristic inconsistencr, charges the Insiitute with not being independent, and with being " placed directly under their control!" while here, he says, they are shaking off all connexion with the College of Surgeons! This is blowing hot and cold with a vengeance.

The fifth charge is the most extraordinary and most bungling of the whole. "Then, again, at page 16 of the Report, they say, 'that nothing in this Act shall prejudice the chemist or druggist, compounder or vender and dispenser of drugs;" "-this is an inaccurate quotation which MIr. Bottomles makes to damage the Institute; but, Sir, it is in reality an extract from your "Medical Registration Bill," which the council went to Sir G. Grey to strongly protest against, for many reasons, but especially against this very clause in favour of chemists. "Save me from my friends!" So much for Mr. Bottomley at present, though I might add that his conduct to the council of the Institute is a marked contrast to the courtesy and co-operation which he received at their hands, and is in keeping with his broken pledge to assist them in obtaining a new college.
I now refer you and your readers (for the real and independent nature of the college which the council of the Institute have applied to Parliament for) to the Bill recently brought in by Mr. Wyld and Colonel Thompson, and which you have already kindly referred to in a leader of your last number, and remain, Sir, yours faithfully,

Dulwich, August 6, 1850

Geo. Webster, M.D.

\section{MR. BOTTOMLEY AND DR. G. WEBSTER.}

\section{[MR, BOTTOMLEY'S REPLY TO DR. G. WEBSTER'S LETTER} OF JULX 30.]

To the Editor of The LaNoet.

Srr,-My old friend, Dr. Webster, of Dulwich, has made me so censpicuous in the last paragraph of his letter to you in THE LANCET of the 3rd inst., and has so freely favoured his medical brethren with his past, present, and probable future opinions of me and my career, or " tergiversate course," to use his own very eurhonious term, that you will, I think, permit me to make a very brief reply to what, from very few other men, I would have condescended to notice. But Dr. Webster and I are old friends, and I have too much respect for him to pass over his little criticism in silence.

Permit me to say, and that most confidently,- - though I will not dispute the great literary acquirements of $\mathrm{my}$ accomplished friend, who has seen proper to assert that my "extraordinary speech" "sets at defiance all rules of grammar, logic, and common sense", - that nine-tenths of my hearers would and did clearly understand my aim, meaning, and opinion, as expressed in the aforesaid " $\mathrm{ex}$ traordinary speech;" if Dr. Webster did not, his obtuseness is more obvious than the friendiiness of his remarks.

I am a plain man, and am more accustomed to the use of homely and idiomatic expressions than to those long and sonorous combinations of the members of the cross row in which my friend delights.

And what, if his critical eye, so readily and so sorely offended by any little deviation from the rules of Lindley Murray, did perceive a flaw or two in any grammatical construction, let me tell him that few men write perfect grammar in the original draught of any composition. Dr. Webster may have, but I have not, the leisure (nor do I envy his) to write and re-write some half-dozen copies, to acquire the perfection his fastidious taste requires. I can afford, when pressed for time, in the midst of the multitudinous claims of a professional life, to commit a grammatical blunder or two, since men no less distinguished than the Duke of Wellington, and many great officers, have done the same, times without number, in their despatches-a fact too notorious for my literary friend to be ignorant of; but I trust I could not be guilty of so gross a breach of good taste and feeling as to invite public attention to such little shortcomings, on the part of any friend of mine, when circumstances chanced to place me in a position of controversy with him.

Will it not be suggested to every unprejudiced mind, that it is often easier to expose an ungrammatical construction, or to abuse a man's logic, than to meet his argument: a very old trick is this, and dates from Adam downwards.

I shall not trespass further on your limits to notice the Doctor's personalities, nor remark at any length on the kindness he has manifested, in hitherto believing me to have been actuated by "good, though mistaken intentions," in attributing my conduct to the "instance of others ;" and for the very friendly warning, in his own peculiar patronising style, that unless "I apologize to my London brethren" he shall be obliged to form a very different opinion from that he has hitherto entertained of me.

But I rould just reinind him,-and let his superior logical powers enable him to dispute the justness of my inference if they ean,- that I have No "London brethren" to apologize to. I only denounced men who were dealers in quack medicines, \&c., and those who followed quackery in its other forms of hydropathy and homœopathy. These, allow me to tell Dr. Webster, are no "brethren" of mine, and I owe no apology to any such.

If I still am denied his good opinion till these have heard me unsay my denunciation of their objectionable and highly undignified practices, then I must fain continue my path, though it be "as usual, alone," and endeavour to hold on my steady course uncheered and unblessed by my friend's approval and much valued friendship: if they be "brethren" of his, I regret, on his account, the relationship, and much as $I$ esteem the man and the physician, I must sacrifice my own feelings in the matter of his friendship to the dictates of my own better judgment.

I have the honour to be, Sir 